\title{
The Studies of Islamic Areas by European and American Academic Society - Centered on Mainland (50 Years After the Founding of New China)
}

\author{
Alimu Tuoehti \\ Frontier Research Institute for Interdisciplinary Sciences, Tohoku University, Sendai, Japan \\ Email address: \\ tuoheti.alimu@orinst.ox.ac.uk \\ To cite this article: \\ Alimu Tuoehti. The Studies of Islamic Areas by European and American Academic Society - Centered on Mainland (50 Years After the \\ Founding of New China). History Research. Vol. 9, No. 1, 2021, pp. 84-96. doi: 10.11648/j.history.20210901.21
}

Received: February 18, 2021; Accepted: March 8, 2021; Published: April 23, 2021

\begin{abstract}
The studies of Chinese Islam by worldwide academic society are consisted of two schools, "western" and "Japanese". I will focus my research "The studies of Chinese Islam by European and American Academic Society". In this paper, mainly related to the research situation since the second half of the 20th century. Academic research in the second half of the 20th century can be divided into two periods: before and after the 1980s. The characteristics of the two periods are very different Research after 1949 was at a low ebb as Westerners withdrew from China. Regardless of whether they were missionaries or Orientalists, they were no longer permitted to conduct research in mainland China. Given the geopolitical impact of the Cold War, Western research on Chinese Islam inevitably declined. Furthermore, after the Second World War, with the independence of colonial countries, Western disciplines, such as Orientalism and anthropology, gradually lost their traditional prestige. This trend persisted until at least the 1960s, when structuralist anthropology characterized by theoretical construction emerged. In the field of Islamic Studies in China, the same shift took place and Islam in China began to be looked at from the perspective of sociology and anthropology. One of the main characteristics is that, during this period, research was mainly conducted into literature and a number of bibliographical studies were published (as other avenues of research were curtailed). Since the 1970s, and the new opportunities offered by the "Reform and opening-up", Raphael Israeli's works on Chinese Muslims have been published continuously, and have greatly influenced Western academia. In addition to several monographs, he has published more than 20 papers on Chinese Muslims and Islam. Since the 1980s, with the change in China's national policy, Western scholars have once again been able to carry out fieldwork in mainland China. From the 1990s, with the continuous expansion and exchange of academic research between China and the international community, Western study of Islam in China has entered a new stage. Theoretical improvements in research and practical investigation have allowed significant progress, and disciplines and research paradigms in this period have become more diversified. Traditional historical research has combined with anthropology, political science, gender research, and other disciplines.
\end{abstract}

Keywords: European, American, Academic Studies, Mainland China, Second Half of the 20th Century

\section{Historical Background: The Low Tide of Academic Research and Its Turn}

The People's Republic of China was founded in 1949. The Korean War broke out soon after, as did the proxy with America. Following 58 years of the great leap Forward and 60 years of natural disasters, China began a difficult three years of hunger. The Cultural Revolution took place between 1966 and 1976. It ended the policy of "class struggle as the key link" and replaced it with a policy of economic construction. With the historic convening of the Third Plenary Session of the Eleventh Central Committee, the second generation of leaders came into being. After the Cultural Revolution, China's economy lagged, and culture and education deteriorated. The "reform and opening-up" became China's most important motto on entering the 1980s. The second generation of leaders vigorously developed the southern coastal cities, with a "special zone" with a designated focus on economic construction. In the 1980s, 
China's economy recovered rapidly. In 1984, the Sino-British joint Declaration made Hong Kong's return clear. At this time, the third generation of leaders emerged.

In the 1990s, the planned economy was transformed into a market economy. At this time, the third generation of leaders introduced the three Represents. The transformation of "citizen's moral standards" and "governing the country by law" into "governing the country by virtue" marked that moment China became a country of high moral education. This involved comprehensively improving economic construction, and improving the spiritual aspect and moral standards of the whole nation. In 1997, Hong Kong was returned to China. In 1999, Macao was returned.

Numerous momentous international events occurred between 1949 to 2000. These include the Cold War between the USA and the Soviet Union, the Afghanistan War, the Vietnam War, the Korean War, the rise of the Non-Aligned Movement, China's recovery of its legitimate seat of the United Nations, the Western economic crisis, the upheaval in Eastern Europe, the collapse of the Soviet Union, the first Gulf War, the 1997 Asian Financial Crisis, and the Kosovo War. The era of globalization saw a shift from two political superpowers to one superpower, with many other smaller powers in a multipolar world. Such seismic historical events were not conducive to a stable academic environment.

After 1949, Westerners withdrew from China. Regardless of whether these international actors were missionaries or Orientalists, they ceased to enjoy research opportunities in mainland China.

In the $20^{\text {th }}$ century, the China Inland Mission (CIM) continued to develop: with more than 1000 members and became the largest missionary organization in China. By 1949, the number of Chinese believers who had been baptized in the Inland Mission reached over 90,000. In the 1950s, the CIM began to withdraw from Mainland China, completing the withdrawal in 1953. Missionaries were redeployed to the East and other parts of Southeast Asia. In 1964, the CIM was renamed "the overseas missionary fellowship" with its headquarters in Singapore. They inherited James Hudson Taylor (1832-1905), had strong mission aspirations, and preached to overseas Chinese and other ethnic groups in Southeast Asia.

After the Inland Mission's withdrawal from China, it continued to publish its English-language journal China's Millions until 1964. The papers published in the journal at the time reveal that the research activities of the CIM had significantly weakened.

After the liberation of Qinghai in 1949, George K. Harris worked with other missionaries for one year. At that time, $\mathrm{N}$. C. Pateman, a missionary in Yunnan, called for a national movement of contact with Muslims for 15 days from April 1950. [1] Harris, seeking to help non-professional missionaries participate in the movement, published the articles "The Moslem Mind" [2] and "Attempt Great Things for God: The Campaign of April 14th-18th". [3] In December 1950, Harris held a special gathering for Muslims. [4]
In 1951 Laurie C. Wood published "The Reproach of Islam in Northwest China" in China's Millions to remind the Christian church that the two northern areas were the most powerful and the weakest places for Chinese Muslims. [5] After leaving mainland China, Laurie C. Wood was sent to the south of Sima (i.e. Taiwan) to investigate the potential for carrying out missionary work.

About the Society of the Friends of Moslems in China and Friends of Moslems, Claude L. Pickens was a typical Western missionary who devoted himself to preaching Chinese Muslims in China. In his early years, influenced by Samuel M. Zwemer, he had a great interest in preaching to Muslims. He traveled to China in 1926. In 1927, he founded the Society of the Friends of Moslems in China and published the English-language quarterly Friends of Moslems in Hankou, Hubei Province. After the founding of the People's Republic of China, due to ideological differences, most missionaries returned to China, and the Society was dissolved in 1951. Additionally, as a special issue of Christian missionaries on the propaganda work of Chinese Muslims, Friends of Moslems was closed in 1951.

Further to publishing the theories and methods of preaching to Chinese Muslims, the magazine also contained copious information about Hui people, which was a valuable record of the situation. The research results were mainly published in 1949, but from 1949 to 1951 , a few papers were also published. [3]

\section{Research Before the End of the Cultural Revolution}

Given the geopolitical circumstances of the Cold War, the study of Islam in China in the West inevitably fell into a low tide.

After the Second World War, with the independence of colonial countries, the Western disciplines, such as Orientalism and anthropology, which took the study of barbarians and the backward East as their duty, gradually lost the traditional fields. Disciplines such as anthropology, for example, began a more promising academic era. After the 1960s, structuralist anthropology with the characteristics of theoretical construction emerged. Various works, including bibliographies and papers were published.

(1) About the bibliographies:

The following will discuss the most prominent research results on bibliography in this period. One is Claude L. Pickens's book Annotated Bibliography of Literature on Islam in China." [6] The book is divided into eight items: introduction, the introduction of Islam to China, history and development, denomination and association, literature, inherent culture, terminology, and statistics. It introduces the literature of Europe, America, and China with explanations. Its disadvantage is that it does not introduce the research outcomes of Japan and Russia.

Also renowned was Rudolf Loewenthal's "Russian Materials on Islam in China: A Preliminary Bibliography" 
paper. The introduction, "Russian research on Muslims and Islamic countries is little known outside of Russia because the pertinent literature is widely scattered: This bibliography concerns the study of Islam only in China and will be extended later to other Muslim areas. The compiler hopes that it will be possible to assemble all of the listed items (books, pamphlets, and periodical articles) in one central depository in the United States, either in the original or in reproduction. The compiler collected these materials during research trips to American libraries under the auspices of Cornell University, with grants- in aid by the Rockefeller and Ford Foundations (1952/53)." [7] In this paper, 142 Russian documents are listed, which are summarized into four items, including annals, history, economy, ethnography, and population. At the end of the paper, there are names of people and the index of papers.

Additionally prominent is Ludmilla Panskaya and Donald Daniel Leslie's "Introduction to Palladii's Chinese Literature of the Muslims": "This is the twentieth volume to appear in the Oriental Monograph Series of the Faculty of Asian Studies at Australian National University. It is not a monograph according to customary American usage since it goes in several different directions at once, but that is a minor point. More important by far is the opportunity it gives its readers to learn something about the history and the quality of Russian work on China."

The volume includes: 1) a brief history of the Russian Ecclesiastical Mission in Peking; 2) a biographical sketch of Palladii Kafarov and a summary of his sinological work; 3) the translated preface by Nikolai Adoratskii to Palladii's Chinese Literature of the Muslims; 4) Adoratskii's introduction to the same; and 5) an appended bibliography of Palladii's writings with additional references used by the author." [8] The paper first describes the situation of the Beijing mission of the Russian Orthodox Church, then introduces the biography and works of Baladi, a Russian missionary who studied Islam in China. Finally, it attaches the catalog and notes of Baladi's works.

(2) About the books:

The first part introduces Vasilij Pavlovich Vasil've's "Islam in China." [9] The proclamation was handed over in 1862 by Archimandrite Palladius, the Head of the Russian Orthodox Mission in Beijing, to the Russian sinologist Vasiliew, who translated, edited, and published it.

There are books with the same name: "Islam in China" by M. Rafiq Khan: "The story of Islam in China, and especially its position under the present Chinese leadership, is of crucial significance in light of the Communist plan to remold man and society within China and of the direct influence that this plan has no the policies of Moslem states via-av-vis China. This book by Mr. Rafiq Khan, co-director of the Mewat Survey Project at Jamia Rural Institute in New Delhi, which sets out to tell this story, cannot be considered a serious effort." [10]

There a book called Cohesion and Cleavage in a Chinese Muslim Minority by American scholar Barbara Pillsbury, her doctoral thesis. This was based on her fieldwork in Muslim communities in Taiwan after 1949. [11]

There is also a book involving ethnographic surveying: "Muslim Peoples." [12] A relevant review is as follows: "This is the first attempt to examine all the major Muslim communities of the world and to place the results within the covers of one book. The declared aim is 'to discover what they have in common, what distinguishes them from each other, and what they feel is important'. Amongst the 720 million-plus Muslims on the planet some 300 ethnic groups are identified, and of these ninety-six with populations of over 100,000 receive an entry. The size of the groups covered varies hugely from the Arabs and the Bengalis, consisting of 112 and 82 million respectively, to the Divide of the Maldives and the Vai of Wes Africa with about 100.000...." The book also comments on Hui, Uyghur, Kazak, Kyrgyz, Tajik, Tatar, Uzbek, and other ethnic minorities who believe in Islam in China. It is very convenient to use as a reference book.

This book on Islam in China is also salient: China's Forty Million: Minority Nationalities and National Integration inthe People's Republic of China. "The most comprehensive study yet of Chinese Communist policy toward the strategically located national minorities. The author concludes that the party's most conspicuous failures have been in Xinjiang and Tibet, where major rebellions occurred in 1962 and 1959 respectively, and where the participation of minority groups in party and government organs has consistently lagged behind that of minority groups elsewhere. The goal of Communist policy seems to be the abolition of minority culture and forced assimilation although the pace of assimilation has varied from period to period." [13] While studying Hui and other ethnic minorities in China, the also introduces their related beliefs, including Islam in China, but some of them are not correct.

(3) Regarding the papers:

Firstly, the following will overview the papers in English:

"Islamic Culture in China" includes these chapters: The Rise and Fall of Islam in China; The Muslim Community; Islam and Confucianism, Taoism, and Buddhism; Religious Organization of Chinese Muslims; Chinese Muslim Religious Practices; Education and Culture of Chinese Muslims such several angles. It briefly summarizes the Chinese Muslim customs, daily life, the relationship between Islam and Confucianism, Buddhism and Taoism, religious organizations, forms of worship and so on. However, its value of historical narration is not great. [14]

Two other important papers are "Russian Contributions to the History of Islam in China" and Rossabi and Morris' "Muslim and Central Asian Revolts." [15] This first paper mainly introduces four works of Czarist Russia and two works of the Soviet Union. "Some ten to twelve million Muslims are residing in China according to the latest census (1959); about two-thirds of them live in Sinkiang province, where they form an almost solid ethnic bloc. The Russian literature on Sinkiang is extensive and includes translations from various European languages; most of the titles deal with history, archaeology, economics, politics, or military strategy. 
The Russians have been in touch with Sinkiang sporadically sine the second half of the eighteenth century. Their interest became more active after the conquest of Russian Central Asia in the 1860s. This period coincided with severe internal upheavals in China which almost dislodged the Manchu Dynasty: the T'ai-p'ing Rebellion (1850-1864); the Nien-feirevolt (1853-68); the almost simultaneous Muslim uprisings of the Panthays in Yunan province (1855-73) and the subjects of Yakub Beg, who made himself ruler of Kashaaria (1865-77), as well as of the Chinese-speaking Muslim Tunganis (1861-78).” [16]

About the French papers:

Francois Joyaux published three key papers: "Les Musulmans en Chine Populaire," "Les Minorits-Musulmansen Chine Populaire," and "Les Musulmans de Chine et la Diplomatie de Pekin." The first paper includes historical and geographical descriptions but focuses on the situation of Islam in China after the founding of the People's Republic of China. Compared with the description of Hui people in Mainland China, more details are given about the conditions of all ethnic groups in Xinjiang who believe in Islam and belong to the Turkic language family of Altaic. [17] The second paper describes China's policy toward ethnic minorities, particularly Muslim groups, especially in light of the regional autonomy policy. [18] The third paper mainly describes the role of Balkan and others in the implementation of China's policies toward Islamic nationalities. [19]

About the German papers:

Jesef Trippner published "Dir Salaren, Ihre Ersten Graubeans- Streitigkeiten und Ihr Aufstand 1781" and "Islamiche Gruppen und Druberkult in Nord-west Chine." The first paper not only describes the name, origin, relevant records, and living area of Salar but also describes the uprising caused by the struggle among various sects in 1781 . From 1929-1953, Trippner lived in Gansu, Ningxia, and Qinghai, especially in Lanzhou, Wuwei, Zhangye, and Xining. He communicated with local Muslims directly and obtained a lot of original materials. In the paper, he also listed some rare locally published historical materials. [20] The second paper mainly narrates the genealogy and history of the six Menhuan in the "Menhuan system" of the Muslims in Gansu Province. [21]

Another important paper is Herbert Franke's "Eine Mittelaterliche Chinesische Satire auf die Mohammedaner" (A Medieval Chinese Satire of the Muslims). Based on the study of the relevant historical data in the Yuan and Ming dynasties, this paper enumerates various viewpoints discriminating against the Han Muslims. [22]

Regarding a paper in Russian:

In the paper "Dungane; Istorko-eth-nograficheckiiocherk," the so-Called "Dongguan people" refer to all Muslim ethnic groups of the Altaic Turkic language as family, such as Uyghur, Uzbek, and so on, who live in Xinjiang, China and parts of Central Asia and the Soviet Union. During the uprising of the Hui people in the late Qing Dynasty, Bai Yanhu and other Hui people in Shaanxi were chased by the
Qing army and fled. Sanluo believed that the Muslims who migrated to China from the Yuan Dynasty exchanged with the main ethnic party members of the Xixia state as a whole, which led to the formation of the new ethnic "Dongguan people" in Northwest China. Dongguan people are local ethnic groups with the party members as the core. Presently, many people hold this view. They divide the Chinese Hui people, who use the common Chinese language, into two parts: those who live in the Central Plains of Hebei, Shandong, and Henan, and those who live in the northwest of Shaanxi, Gansu, Ningxia, and Qinghai. They believe that the former is Han people and they believe in Islam, while the latter is a mixture of Turkic Muslims and Han, namely, "Dongguan" people. Indeed, Su Sanluo proposed some new ideas, but they still required discussion. [23]

In this period, Svetlana Rimsky-Korsakoff Dyer published several papers: "Soviet Dungan; the Chinese Language of Central Asia, Alphabet, Phonology, Morphology"; [24] "Soviet Dungan Nationalism; A few Comments on Their Origin and Language"; [25] "Soviet Dungan Weddings: Smbolism and Traditions" [26]; and "Muslim Life in Soviet Russia: the Case of Dungans." [27] She was an expert on Dongguan people who lived in Central Asia during its Soviet Union period. Starting from the study of Dongguan people's language, she conducted a comprehensive study of Dongguan people and completing a field trip.

\section{New Opportunities After the "Reform and Opening-up"}

Following the end of the Cultural Revolution, the "Reform and opening-up" marked China's return to the international system in the 1980s. In the 1990s, The Cold War era ended with the collapse of the Soviet Union. The era once again provided an opportunity for academic transformation. There are three characteristics to be noted in this period: first, the emergence of academic works based on fieldwork; second, the further development and deepening of literature research of the previous period; third, the emergence of a large number of monographs. The following will be discussed separately.

Since the 1970s, anthropology with the characteristics of theoretical construction has materialized. In the research field of Islam and Muslim issues in China, has been a tendency to study and construct the theory of Chinese Islam with sociological and anthropological theories. The most notable representative of theoretical construction is Raphael Israeli.

\subsection{Raphael Israeli and His Publications}

Raphael Israeli received his Ph.D. from California University at Berkeley. Since then, he has been engaged in the study of Chinese and Islamic history at the Hebrew University of Jerusalem. From the 1970s, his works on Chinese Muslims have been published continuously, which have had a great influence on Western academic circles.

In addition to several monographs, he has published more 
than 20 papers on Chinese Muslims and Islam. Israeli's research on Islam in China is not only fruitful but also has formed his unique theoretical Position, providing influence and representation in Western academia. His research on Islam in China is mainly concentrated on Chinese Muslims, and his achievements in this field are mainly reflected in the book: Muslims in China: A Study in Cultural Confrontation.

This book principally discusses the following questions: 1 . The relationship between Han and Hui, 2. Are Hui people Han? 3. Han Hui and Chinese Muslim, 4. Hui Society in China, 5. Muslims in China and Islamic Groups around the World, 6. Muslim and Han, 7. Islam and Judaism in China, 8. Islam and Christianity in China, and 9. Islam in India and Islam in China.

Based on the sociological theory of ethnic relations, the book proposes that the Han and Islamic cultures encounter each other in a typical firm relationship between the main ethnic groups: the host culture and the guest culture, respectively. The derived problems are arranged from acculturation to confrontation, which can be divided into three stages of cultural change. The syllogism of this cultural conflict presupposes the tragic ending of Islam in China, specifically, that Muslims cannot survive peacefully in China for a long time. In one regard, his research provides ample inspiration, that is, to understand the history of Islam in China from the perspective of Hui culture; conversely, it also shows its arbitrariness and superficiality, namely, its theory cannot explain the reality of Hui Islam.

A relevant review of Muslims in China: A Study in Cultural Confrontation is as follows: "Muslims constitute China's largest religious minority and include the single most widely distributed of all China's minority nationalities. Throughout the Islamic world, however, no major community of Muslims is so little understood by outsiders as is China's. Dr. Israeli is to be complimented, therefore, for attempting the first book-length overview of this complex subject to be published in any western language since 1910 . Unfortunately, however, while the book provides an intriguing glimpse into the conflicts that have occurred between Han Muslim Chinese, readers seeking either a clear understanding of those conflicts or of the contemporary relationships, will have to continue to wait." [28]

Overall, this book uses sociological methods to analyze the relationship between the ethnic minorities who believe in Islam and the Han nationality, the predominant ethnic group in China. Simultaneously, it places Chinese Islam in the context of global Islam. Widely recognized by the academic community, it is regarded as one of the most representative works between in the 1950s and 1970s. [28]

In 1994, Israeli published a detailed reference book on the study of Hui Islam in China: Islam in China: A Critical Bibliography. A preview is as follows:

"Reference works are not intended to be read from cover to cover; this book is no exception. One can easily utilize the 10 main categories (Bibliographies and Inscriptions; General Works, Imperial China, Republican China; the People's Republic; Culture, Religion, and Theology; Social Discontent and Political Upheaval; Local Reports [by geographic regions]; Jews in China; Missionary Reports) and the helpful indexes to guide the search to needed materials. In this case, however, the brief Introduction and essay on "Islam in China," offers the user a general context for all the topics referenced in the volume and also guides the reader to specific entries (unfortunately, there are some transposition errors that may cause come confusion e.g., on p. xviii the reference to 1019 should be 0019). Furthermore, these introductory materials make clear the limits of the undertaking by specifying that selections included are those deemed most significant on the western language sources and directs the user to other works that deal with sources in Arabic, Chinese and Japanese (p. xvii)). [29] The detailed catalog, detailed classification, and convenient retrieval provided by this book make it an important reference book in this research field. For those who need to understand the western academic research on Hui Islam in China, there is no doubt that this book can play a role. That's what the review says: "Bibliographies are the lifeline of the researcher and for those interested in studying and writing on China's largest minority, the annotated bibliography Islam in China: A Critical Bibliography by Raphael Israeli is an excellent place to start. With the help of Lyn Gorman, this reference work, the Greenwood Press Bibliographies, and Indexes in Religious Studies series are logically organized and easy to use. Few people, if anyone, are better suited than Israeli to produce such a helpful volume. The author index (there are also the title and subject indexes) quickly reveals that there are more entries under his name than any other scholar. The care with which the annotations are done makes it clear that he has used much of the material included in the volume in his research."

\subsection{Raphael Israeli’s Paper}

Raphael Israeli's paper, "The Cross Battles the Crescent: One Century of Missionary Work among Chinee Muslims (1850-1950)":

In this paper, the author examines the 100-year history of Christian missionaries spreading among Chinese Muslims from 1850-1950. It is believed that the response of Chinese Muslims to Christian missionaries presents many different possibilities between the two extremes of "acceptance" and "rejection." Additionally, the Western missionaries' attitude toward Chinese Islamists is contradictory. In one regard, they believed that Chinese Muslims were accessible. Conversely, the missionaries considered the Muslims difficult to deal with The author also discusses the interaction between Muslim and Christian missionaries in different cases. The author believes that although the Christian missionaries tried to make the work with Chinese Muslims rely on the gospel, on the whole, the relationship between the two was neither fixed nor one-way from Christianity to Islam. The two were dialectical. They challenged and responded to each other symbiotically and faced each other directly. This article is full of benefits, particularly in including numerous kinds of publications relating to the relationship between Christianity and Islam within China. [30] 
"The Muslim Revival in $19^{\text {th }}$ Century China":

"For the Muslims in China, communal survival in a Chinese environment had been of paramount importance throughout their history. Up to the advent of the Ch'ing Dynasty (1644-1911), Chinese Muslims had attempted to abide by a low-profile image, they avoided friction with the Chinese, and they refrained from any overt missionary work which would have exposed and indicted them as heterodox. Their existence in China was not easy but it was not untenable. As long as they could live as Muslims, in their communities, they were prepared to incur inconveniences, smooth over difficulties, and conform, at least outwardly, to the requirements of the Chinese host culture." [31]

"Muslims in China: Incompatibility between Islam and the Chinese Order":

"Muslim presence in China, which dates back to the T'ang Dynasty, has always posed a challenge, at times even a threat, to the Chinese establishment. This was due to that Islam, far from willing to acculturate into Chinese society, on the contrary, nurtured its distinctive traits and stressed its superiority, something almost unheard of in other minority cultures in the Middle Kingdom.” [32]

"Established Islam and Marginal Islam in China: From Eclecticism to Syncretism":

"When Islam came to China during the Tang Dynasty $\left(7^{\text {th }}\right.$ $-10^{\text {th }}$ centuries), and for a long period thereafter, there was no question of the Muslims Sinicizing or the Chinese Islamizing. Islam was brought to the Middle Kingdom by Persian and Arab traders who remained in constant contact, until the end of the Mongol rule in China ( $14^{\text {th }}$ Cent.), with their countries of origin. Although they settled in China, they remained out of it, so to speak, because of the virtual extra-territorial rights accorded to them, together with the freedom to conduct their lives as they wished. Neither did the Muslims in China attempt to spread their faith overtly, because they must have been aware, from the very outset, of the vitality of the Chinese system and of the strength of the unitarian Chinese state attached to that system, which would make any mass Islamization unlikely if not impossible.” [33]

"Ahung and Literatus: A Muslim Elite in Confucian China":

"Religion in China was closely intertwined with intellectual life and with the political and social institutions of the nation. Confucianism was identified with scholarship wad was deeply entrenched in the habits of thought, affections, and loyalties of the educated people. The state was committed to the existing faiths. Especially Confucianism, Confucian classics were the basis for education and the examination system. Ceremonies were associated with Confucianism and maintained at public expense. Officials, including the Emperor, performed many of the duties usually assigned to the priesthood in other cultures. The very political theory on which the state rested derived its authority from Confucian teachings. Religion also formed part of the village life. Temples were maintained by villagers, and festivals and ceremonies took place through general contribution. Guilds had patron-Gods and other religious features. Above all, the family, the strongest social unit, had as an integral part of its structure the honoring of ancestors by rites that were religious in origin and retained religious significance." [34]

"Muslim in China: Islam's s Incompatibility with the Chinese Order":

"Muslim presence in China, which dates back to the T'ang Dynasty, has always posed a challenge, at times even a threat, to the Chinese establishment. This was due to that Islam, far from willing to acculturate into Chinese society, on the contrary, nurtured its distinctive traits and stressed its superiority, something almost unheard of in other minority cultures in the Middle Kingdom." [35]

"An Arabic Manuscript on China and Tibet":

"Ever since western orientalists took interest in Arabic geographic accounts, a score or so of Arab geographers who had either traveled to the Far East or, more often, collected hearsay and stories from secondary sources about the marvels of those lands, have been translated into European languages. More texts of this sort, in Persian and Turkish, were translated, edited, and published over the years. The most recent of Arabic manuscripts touching upon China was published by Richard Frye in 1949." [36]

"The Cross Battles the Crescent: One Century of Missionary Work among Chinese Muslims (1850-1950)":

Here are his main research results:

\footnotetext{
"The Muslim Minority in Traditional China," Asian and African Studies, Vol. 10, No. 2 (1975): 1010-126.

"Muslim Versus Christians in China," Asia Quarterly, Vol. 4 (1976): 327-335.

"Islam and Judaism in China: The Merger of Two Cultural Subsystems," Asian Profile, Vol. 5, No. 1 (1977): $31-42$.

"The Hui under the Manchu," Studia Islamica, Vol. 49 (1978): 159-179.

"Islamization and Sinification in Chinese Islam," In Conversion to Islam, edited by N. Levtzion, 159-176, New York: Holmes and Meir, 1979.

"Muslim Minorities under Non-Islamic Rule," Current History, (April 1980): 159-164, 184-185.

“Islam in China," In Abingdon Dictionary of nary of Living Religions, 358-359, Nashville: Abingdon, 1981.

"The Muslim Minority in the People's Republic of China," Asian Survey, Vol. 21, No. 8 (August 1981): 901-919.

"The Crescent in the East," ed, Riverdale: The Riverlale Company, 1981.??

"Islam in China," In Cambridge Encyclopedia of China, 330/332, Cambridge: Magnes Press, 1982.

"Islam in Asia, Vol. 2: Southeast and East Asia," Israeli and Johns A., eds, Jerusalem: Magnes Press, 1984, (5016) se

"Les Musulmans chinois," Mythes et Croyances du Monde entire, Paris: Edition Lidis, vol. 2 (1985): 442-449.

"Muslim Rebellions in Modern China: A Part of, or a Counterpart to, Chinese Revolution?," In Studies in Islamic History and Civilization, edited by M.

Sharon, 291-303, Leiden: Brill, 1986.

“China's Muslims," In The World's Religions: Islam, edited by P. Clarke and F. Hardy, 102-118. London: Routledge. 1998.

"Is There Shi a in Chinese Islam?," Journal Institute of Muslim Minority Affairs, Vol. 9, No. 1, (1988-89): 49-66.

"The Naqshbandiyya and Factionalism in Chinese Islam," Naqshbangdis, edited by M. Gaborieau, The. Zarcone and A. Popovic, Paris: Editions Isis, 1990.
} 
After 1949, many missionaries or Orientalists who studied the issue of Chinese Islam and Muslims left or changed their research direction with various changes in China's relations with Europe and America. However, several scholars and research continued to work on Islam in China. To some extent, the unremitting efforts of these scholars promoted the study of Islam and Muslims in China, which had been depressed for some time after 1949.

Among them, Raphael Israeli is the most representative scholar. His above research result has made great contributions to the study of Chinese Islam and Muslims. We will continue to introduce other scholars.

\section{Academic Works Based on Field Work}

Since the 1980s, in the context of China's economic reform and "opening-up," Western scholars have been able to carry out fieldwork in Mainland China. Since the 1990s, with continuous expansion and exchange of academic exchanges between China and the international community, the study of Hui Islam in China in the Western world has entered a new stage. Both theoretical improvements and practical investigation and research have made significant progress. Compared with the past, the disciplines and research paradigms in this period are more diversified. There is not only traditional historical research but also the participation of anthropology, political science, gender research, and other disciplines in recent development. The research is also more reflective. Among the many Western academic studies of Chinese Islam in the middle and inland areas, Du Lei, a famous American anthropologist, has conducted field research in Northwest China many times and has written five monographs with great academic weight and value, including his book "Muslim Chinese: Ethnic Nationalism in The People's Republic." [37] This book not only has some achievements in ethnic group theory but also represents a pioneering significance in the study of Chinese ethnic minorities and Chinese Muslims in Western academia.

\subsection{Dru C. Gladney and His Studies}

Among Western scholars who have studied Chinese Islam and Muslims, Gladney is the most influential thus far. In his early years, Gladney studied Chinese and traveled to Hong Kong and other places, discovering the complexity and diversity of Chinese society. During his university studies in anthropology, he chose to study Islam and Muslim issues in China. In 1981, Gladney, a doctoral student in anthropology at the University of Washington, went to Beijing University to study Chinese. Subsequently, he has focused on Chinese Muslim people. In 1983-1985, as a scholar of Fulbright and National Academy of Science, he visited China again for fieldwork, and for the following six years, he traveled in China every year. Finally, based on his doctoral thesis, Muslim Chinese: Ethnic Nationalism in The People's Republic," he achieved this book. [38] His work, with its very similar first-hand materials and unique research perspective, is worthy of being the most 1980s and established his position in the Western Chinese Islam research community. In the next few years, the book was reprinted, and at least eight scholars write special comments on it within three years of its publication. In 1998, he published a new book based on this work: Ethnic Identity in China: The Making of a Muslim Minority Nationality. [39] In addition to the above two monographs, Gladney also published many papers on the study of Chinese Islam and Muslims in various magazines, with great influence.

About Muslim Chinese: Ethnic Nationalism in The People's Republic:

There are seven chapters. These encompass: Nationalism of Chinese Muslims; Ethnography and Chinese Society; The revival of national religion in the Sufi Community in Northwest China; National identity of Niujie: The urban experience of Hui nationality; Internal marriage system of Hui Autonomous Township; Southeast Hui's Identification and state involvement; and National identity in China. Gladney's work is based on an investigation of four different types of Hui communities, namely: Najiahu, a village in Ningxia represented by the village community, Niujie in Beijing, represented by the Hui community in the Eastern city, Changying Hui Township in the suburbs of Beijing, represented by the Hui rural community in North China, and Chendai Hui town in Quanzhou Fujian, represented by the Hui community on the southeast coast. To explain the differences of Hui culture and the unity of Hui national identity with the theory of relationship approach, Gladney made the Najiahu Hui community Sufei (Sufei means Islamized), and the Chendai Hui community Sinicized, thus denying the common cultural basis of Hui existence, to fit his theory to build the national policy and Hui's running in to produce the Hui nationality. Therefore, in the specific interpretation of the Hui nationality in China, Gladney's relationship theory has laid a subjective foundation for the Hui nationality.

Many aspects of Dru C. Gladney's works can be learned from. First, he deconstructed the homogeneity of the Hui nationality and revelated the diversity of the Hui nationality's identity, transcending Israeli's view of the Hui nationality as a whole. Second, he promoted the study of Hui nationality to the international dialog of ethnic theory, such as refuting Huntington's theory of Clash of Civilizations with Hui nationality as an example. Third, he had a solid understanding of the Hui identity. On the whole, he found the word Qingzhen-halal and then sought different interpretations of the term by Hui people from all over the country: religious beliefs in the northwest, dietary taboos and professional characteristics in the city, and marriage networks in the rural areas of North China and lineage on the southeast coast. Fourth, he is the first Western scholar to study Hui Islam completely based on field investigation.

About Ethnic Identity in China: The Making of a Muslim Minority Nationality:

There are seven chapters: The uniting of China; Creating 
Muslim identity in China; Inventing the Hui nationality in the Chinese state; ethnoreligious resurgence in a northwestern Sufi community; Chang Ying-Marriage and identity maintenance in a Hui autonomous village; Niujie - the urban Hui experience in Beijing; Chendai-ethnic revitalization in Quanzhou, Fujian; and Conclusion-ethnic national identity in the contemporary Chinese state.

This book addresses the common misperception of China as a monolithic nation-state, when, in fact, it is a potentially threatening country due to its size and homogeneity. Following the revolution and Chiang Kai-Shek's retreat to Taiwan, over 400 separate ethnic groups applied for state recognition. Of the 55 officially recognized, the Huis are the largest Muslim nationality and third-largest minority group. Gladney explores the complexity of the Hui identity, affirming China as a multicultural and ethnically diverse nation, whose potential ethnic separatism has increasingly become a great concern. This case study is one of a series in cultural anthropology, designed for the student in the beginning and intermediate stages of social sciences."This case study introduces students to the problems of ethnic diversity in China, modern nation-states that are normally thought of and taught as culturally monolithic. By introducing students to the wide diversity of identity within one nationality, they are exposed to the ethnic complexities as well as to the larger issue of ethnic pluralism in modern nation-states. Students' perceptions regarding other societies, as well as our own, are challenged and broadened." [40]

Since 1991, Gladney has published four books and dozens of papers, most of which involve the issue of Hui or Chinese Muslims.

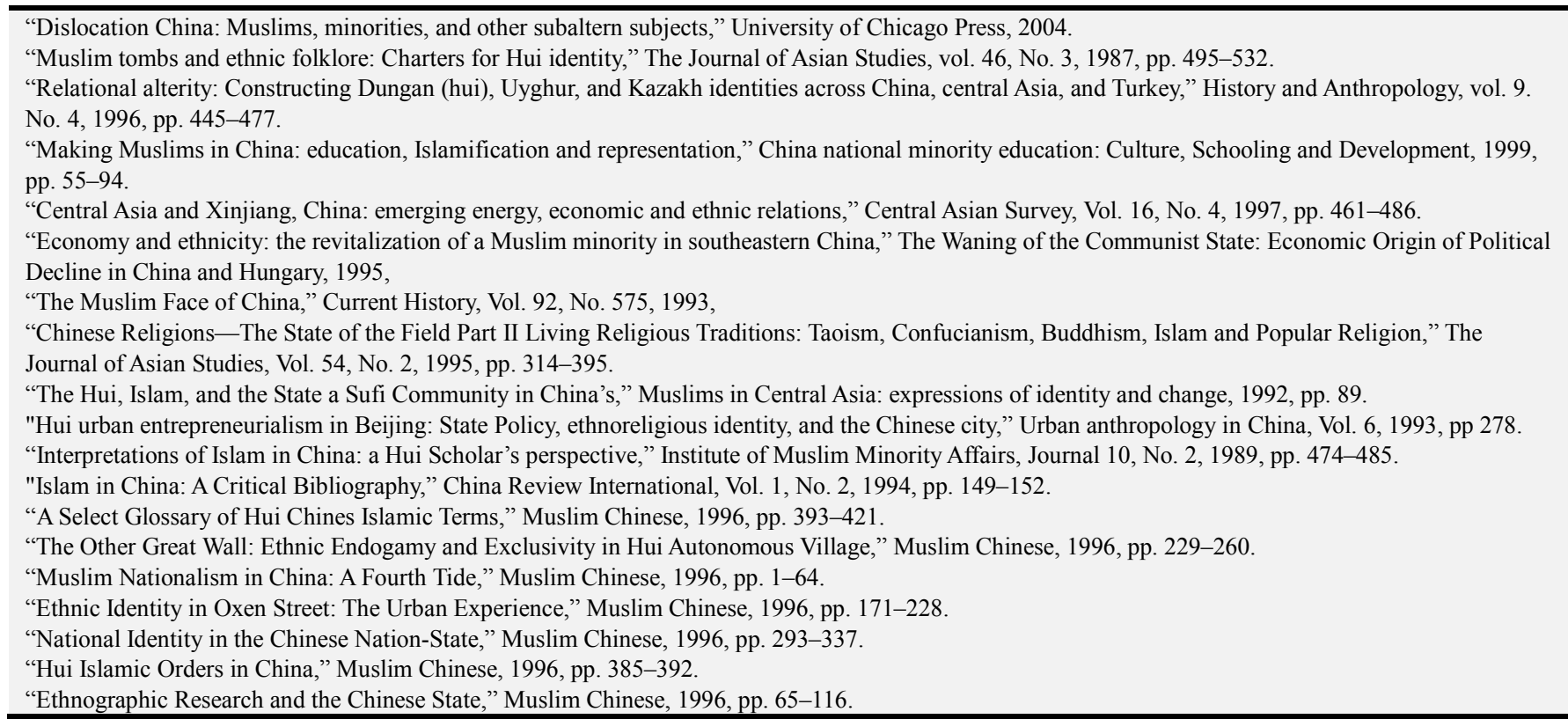

(These are the research outputs prior to 2000).

In one regard, Gladney and his work, it challenges the "imagination" of Chinese and foreign scholars on the definition of the Chinese nation. Simultaneously, it also discusses how a nation's identity is shaped at the local social level by these "social images" and "derivative discourse" of nationalism and ethnicity in China (Dru Gladney 1996, Preface p. XVI). Gladney's research comes from a strong motivation for cultural anthropology and political science. Additionally, the study of modern Chinese Muslims from multiple sides and perspectives can be said to be the study of cultural anthropology, which studies the characteristics of Hui nationality, nationalism more broadly, the status of ethnic minorities, and other issues. To study the Hui nationality, the author spent about three years in China, heard and witnessed the on-ground circumstances of Hui people in Gansu and Ningxia. Gladney's research not only provides a great revision to the existing popular ethnic group theory in the West but also differs from traditional anthological research in research methods, which involves the major issues of anthropological fieldwork and research methods, and it is inevitable to cause special attention and debate.

\subsection{Other Academic Works Based on Fieldwork}

About the other academic works based on fieldwork, in 1996, Wang Jianping published his doctoral dissertation, Concord and Conflict: The Hui Communities of Yunnan Society in a Historical Perspective, [41] which was based on the author's life and investigation in the Yunnan Hui region. A review of the text: "Yunnan Province" is home to roughly half a million Hui: Muslims whose mother tongue is Chinese and who share much of their cultural inventory with the Han majority. Concord and Conflict, as the title indicates, seeks to examine the degree to which this Chinese-speaking Muslim minority is socially and culturally integrated with the non-Muslim majority, and the degree to which its alien origins and religious beliefs keep it separated from, and potentially in conflict with, Han Chinese society and civilization. 
Islamists, as well as historians, anthropologists, and political scientists who specialize in China's national minority peoples and Yunnan's social and cultural affairs, should be interested in this volume. Wang, a son of Yunnan, persevered with an alien language in a strange environment (see p. 12), and although his book is written in less than elegant prose, it is packed with important data, most of it hitherto available only in Chinese. (The Chinese language section of Wang's bibliography, with some three hundred titles, constitutes a major bibliographic resource on the subject of Islam and Muslims in southwest China.)" [42]

A Japanese scholar noted in the journal Eastern that Wang's book was the "first systematic study on the Yunnan tribe" and that it is very high quality. [43] The publication of his book also represents a new stage of field research on Chinese Islam and Muslims since 1949.

\section{The Development and Deepening of Research of Literature, History, and Other Aspects}

In the geopolitical situation of the Cold War, the Western study of Chinese Islam declined. Orientalism and anthropology gradually lost their traditional prestige. In the field of research on Chinese Islam and Muslim, the same turn has taken place: during this period, the research mainly focused on literature. The scholars who proved proficient at literature research in this field were the American Joseph Fletcher and Australian Donald Daniel Leslie.

\subsection{Joseph Fletcher and His Student Jonathan Lipman and Their Studies}

$\Phi$ With rich language knowledge and a profound historical background, Joseph Fletcher translated some Islamic works written by Wang Daiyu and Liu Zhi into English and briefly introduced their academic works and insights, as well as Ma Zhu and Ma Dexin. Unfortunately, Ford's English translation has never been officially published, although some scholars later used his translation in their research. Fletcher has several published research results, e.g., "Chinese Sufism Taoism" [44] and Studies on Chinese and Islamic Inner Asia. [45]

The "Chinese Sufism Taoism" paper was supported by classical Chinese (official document of the Muslim uprising in Northwest China in the second half of the $19^{\text {th }}$ century), Persian, Arabic, Turkic, and Japanese. This paper, with a kind of authoritative reliability, brings Chinese Sufism onto the world stage, providing the twists and turns of local history.

The Studies on Chinese and Islamic Inner Asia book makes a detailed study of the Naqshbandiyah order of Sufism of in China and the Hufeiyah and Zhehlinyah groups of Hui people in the northwest. He has also written papers such as "The Naqshbandi order in Northwest China" and made a thorough and precise study of the relationship between China and the Soviet African origin in the Islamic region of Central Asia, which is well-known in international academic circles.

Due to Fletcher's early death, a large number of collected materials have not been further studied. Therefore, this book in only a part of its academic achievements. The rest has been inherited and developed by his student, Jonathan Lipman.

Jonathan N, Lipman inherited and developed Joseph Fletcher's research tradition. In his doctoral dissertation "The Border World of Gansu, 1935-1985)," he used many original Chinese materials. He conducted unique research on the relationship between the local and central governments and Hui nationality and the legal application of the feudal dynasty to Hui nationality. In more recent years, which was based on his doctoral dissertation, he published the book: Familiar Strangers: A History of Muslims in Northwest. [46] Lipman's transcendence of Fletcher lies in that he has not only confined himself to literature research but also injected theory into it. In the era of post-modern deconstruction, Lipman positioned his research on the Hui nationality in the northwest on the reflection and query of academic discourse such as race. He tended to make specific analysis on specific historical events and figures, rather than build a grand narrative of the Hui nationality history. Lipman describes the Muslim society in Northwest China as a society with dual characteristics on the edge of China, which is not only a largely Muslim society lacking in Islamic social adjustment mechanism but also a Chinese society lacking in East China's social adjustment mechanism, especially the gentry class. His use of the term "familiar stranger" reveals a unique form of interaction between Muslims and Chinese society at large.

Furthermore, a group of scholars from Japan, Britain, France, the United States, and other countries have a strong interest in the study of Hui Islam. Many people, as visiting scholars, have conducted field research in China, aiming to contribute groundbreaking academic achievement.

Lipman also published the papers "Nationality and Politics of the People's Republic of China: The Malanite Warlords in Gansu Province" and "Pieced together and Meshed Society: A Study of the Chinese Muslim Order." [47] The first paper describes the relationship between the three most powerful Muslim families in Northwest China and the Chinese government from the end of the $19^{\text {th }}$ century to 1920 . One family converted to Sufism, while the second family supported a kind of Islam which had been Confucianism, and the third maintained a semi-independent military force under the influence of Wahhabism. [48]

\subsection{Donald Daniel Leslie and His Studies}

Donald Daniel Leslie, an Australian scholar, is a key representative of literature research in Chinese Islam. He also possesses profound language skills and the ability to organize historical materials. In 1981, he published the book Islamic Literature in Chinese Late Ming and Early Qing: Books, Authors and Associates." [49]

In 1982, Leslie published "The Identification of Chinese Cities in Arabic and Persian Sources" and "Arabic and Persian sources used by Liu Chi," studying the names of Chinese cities in Arabic and Persian. [50] The next paper, "Liu Chih, the leading Chinese Muslim writer of the early 
$18^{\text {th }}$ Century, provides two lists of Arabic and Persian sources he had used in writing two of his key works, the T'ien Fang Hsing-lion Muslim Philosophy, c. 1704, and the T'ien-fang Tien-li on Muslim Law and Customs, c 1710. Pelliot described these lists as "en Somme un catalog des overages arabes et persans connus en chine vers 1700." [51] In sum, these were very professional studies of Chinese Islamic classics.

In 1986, Leslie published his masterpiece Islam in Traditional China: A short History to 1980. [52] The main body of the book is divided into four parts: the first in "China and Western Asia," which studies the relationship between China and Western Asia in Tang Dynasty and earlier; the second part is "The Beginning of Islam in China," mainly examining the history of Islam in the Tang and Song dynasties; the third is "Under the Rule of Mongolians," which discusses the history of Islam in the Yuan Dynasty; and the fourth part is "Sinicization: Ming and Qing Dynasty," investigating the history of Islam in the Ming and Qing dynasties. The book has a unique style of writing the history of Islam in China and fully reflects the author's ability to interpret Chinese, Arabic, Japanese, and European texts.

Leslie also published "Islam in China to 1800: Bibliographical Guide" and "Arabic and Persian Sources Used by Liu Chih" papers. The first paper covers a wide range, not only introducing the literature but also the catalog of the books in the library, proving as an irreplaceable bibliography. [53] In the second paper, in cooperation with Wassel, he examined the original titles of the Islamic documents quoted in the $18^{\text {th }}$-century Chinese Islamic scholar Liu Zhi's "Tianfangdianli, Tianfangxingli" Leslie concluded that the Islamic documents quoted by Liu Zhi were mainly of Sunni Hanafi schools, and the Persian language was mainly a Shafei instrument. Generally speaking, Persian is more than Arabic. [54]

It pertains to Leslie's research: "The Origin of Islam in China." This article can supplement the Muslim special collection catalog compiled by Leslie in the world's major libraries. [55]

\subsection{Michael Dillon and His Studies}

In 1996, Michael Dillon of France published a pamphlet called "China's Muslims." [56] A relevant review is as follows: "Muslim communities are found in every Chinese province and Muslims play a prominent part in the modern Chinese state. In an illustrated book directed at scholars and travelers alike, Dillon examines each of the country's ten Muslim groups: he sketches the history of its arrival in China, explains its languages and customs, and describes the work and daily life of its members. Dillon includes portraits of the most important Muslim centers, from Hui towns of the Ningxia region to the Uyghur city of Kashghar near China's western boundary." [57]

Leslie also published the book China's Muslim Hui Community: Migration, Settlement, and Sects. [58] The contents are divided into: Ethnicity and Hui history; China and Islam before the Ming Dynasty; The Hui during the Ming Dynasty; Hui Communities under Manchu Rule; Hui
Insurrections in the nineteenth century; Hui Communities in Early twentieth-century China; The Islamic Background; Sufi Orders in China; The Xidaotang; Language and the Hui; Hui Communities in Contemporary China; and Jews and the Blue-capped Hui.

"This is a reconstruction of the history of the Muslim community in China known today as the Hui or often as the Chinese Muslims as distinct from the Turkic Muslims such as the Uyghurs. It traces their history from the earliest period of Islam in China up to the present day, but with particular emphasis on the effects of the Mongol conquest on the transfer of Central Asians to China, the establishment of stable immigrant communities in the Ming Dynasty and the devastating insurrections against the Qing state during the nineteenth century. Sufi and other Islamic orders such as the Ikhwani have played a key role in establishing the identity of the Hui, especially in Northwest China, and these are examined in detail as is the growth of religious education and organization and the use of the Arabic and Persian languages. The relationship between the Chinese Communist Party and the Hui as an officially designated nationality and the social and religious life of Hui people in contemporary China are also discussed. The book is an English translation of Ma Tong's $A$ Brief History of Chinese Islamic Sect and Menhuan System, [59] which has little reference value for Chinese scholars.

\subsection{A Study of History and Other Aspects}

The achievements in the study of history are as follows:

Barbara L. K. Pillsbury, "The history of Muslims in China, a Chronology from 1300": This paper gives a comprehensive introduction to the chronology of Chinese Muslims. The author is a political scientist concerned with China and an expert on the issue of "ethnic minorities" in China. [60]

Andrew. D. W Forbes, Warlords and Muslims in Chinese Central Asia: A Political History of Republican Sinkiang (1911-1949): The contents of the book are divided into: The administration of Yang Tsenghsin; The Cconomy of Sinkiang under Yang Tsenghsin; The Annexation of the Khanate of Kumul; The First Invasion of Ma Chungying; The Outbreak of Rebellion in the South and the Collapse; Turkic Factionalism at Kashgar and Yarkand; Tungan Invasion, Turkic secession and Soviets; the Muslims under Sheng Shihtsai; Muslim Separatism under the Kuomin; the Muslims on the eve of the communist; The Constitution and Composition of the Turkish lslamic; and Schemes of Romanization. This is a very incisive work of political science, based on new materials in different languages. It depicts a grand picture of the turmoil in the Republic of China, in sharp contrast to what had been previously produced. Historical figures such as Yang Zengxin, Jin Shuren, and Sheng Shicai in the modern history of Xinjiang are discussed. Religion in this area is not in a position of antagonism with the Central Plains. This is also indicative for both non-believers and Muslims. He also has several articles about the transportation of the Hui horse gang in Yunnan. [61]

Morris Rossabi was an expert on Ming history and Kublai Khan, his research involving the history of Chinese Muslims 
in the Yuan and Ming Dynasties. He published China and the Islamic World. [62] He also wrote a large entry entitled "Islam in China" for the Encyclopedia of Religion. [63]

Abdul Wahid Radhu, "Islam in Tibet-Tibetan Caravans": "This book is the most complete and definitive work on the subject of Islam in Tibet to date. It will be of interest to both scholars in the field and general readers interested in the Islamic community at large, as well as those interested in Buddhist and Muslim spirituality. It features numerous photographs of the present Muslim community in Lhasa today, as well as photographs from the past. Included in its entirety is Tibetan Caravans by Abdul Wahid Radhu, describing his family's centuries-old trading business between India, Central Asia, and Tibet-focusing especially on the fascinating interplay between the traditional cultures of Islam and Buddhism." [64]

Benson, Linda, and Ingvar Svanberg. China's Last Nomads:[65] "China's Last Nomads is the latest addition to the publications by Linda Benson and Ingvar Svanberg on the history and modern development of the Kazak people in China. While Benson's research focus has been on Xinjiang's Moslem minorities, Svanberg's interest is concentrated more on the history and culture of the people of Kazak nationality, be that in Kazakhstan, China, or elsewhere. This new work represents the convergence of their research interests and represents further fruition of their collaboration." [66]

\section{Conclusion}

The academic research in this half century can be divided into two periods: before and after the 1980s. Indeed, the characteristics of the two periods are different. For example, before the 1980s, it was a "low tide" period. After 1949, all kinds of Western forces were forced to leave China. Regardless of whether they were missionaries or orients, they were not permitted to investigate in China. Under the geopolitical situation of the Cold War, Western research on Chinese Islam inevitably decline. After the Second World War, with the independence of colonial countries, Western disciplines, such as Orientalism and anthropology, gradually lost their traditional prestige. This low tide of research trend persisted until the $1960 \mathrm{~s}$, when there was a tendency to restart some studies. Taking anthropology as an example, it was this era that prompted its academic turn. After the 1960s, the structuralist anthropology characterized by theoretical construction emerged.

In the field of Islamic Studies in China, the same shift has taken place. $\circ 1$ One of the main characteristics is that, in the research in this period, literature research was the main feature. $\circ 2$ Another research feature is that there has been a tendency to study Islam in China from the perspective of sociology and anthropology.

After the 1970s, Raphael Israeli's works on Chinese Muslims were published continuously, which had a great influence on Western academy, Simultaneously, his research puts Chinese Islam under the background of global Islam. Widely recognized by the academic community, he is regarded as one the most representative researcher between the 1950 s and 1970s.

Since the 1980s, with the change of China's national policy, Western scholars have been able to carry out fieldwork in Mainland China, especially since the 1990s. With continuous expansion and exchange of academic exchanges between China and the international community, the study of Hui Islam in China in the Western world has entered a new stage. Both theoretical improvement and practical investigation and research have made great progress. Compared with the past, the disciplines and research paradigms in this period are more diversified. There is not only traditional historical research but also the participation of anthropology, political science, gender research, and other disciplines in recent development. The research is also more reflective. Among the many studies of Chinese Islam in the middle and inland areas in Western academic circles, for example, Du Lei, a famous American anthropologist, has conducted field research in Northwest China numerous times. Not only have some achievements in ethnic group theory been made but also a pioneering significance in the study of Chinese ethnic minorities and Chinese Muslims. An important characteristic of this period is that that the research mainly focused on literature.

\section{Funding}

This work was supported by "Leading Yong Researcher Overseas Visit Program" (Tohoku University, JAPAN), February 1, 2020 to January 31, 2021 (one year), Research University: University of Oxford (Faculty of Oriental Studies).

\section{References}

[1] N. C. Pateman, "Islam in China", China's Millions, Vol. 76, No. 4, 1950, p. 37.

[2] George K. Harris, "The Moslem Mind", China's Millions, Vol. 76, No. 5, 1950, p. 58.

[3] George K. Harris, "Attempt Great Things for God: The Campaign of April $14^{\text {th }}-18^{\text {th }}$, Friends of Moslems, Vol. 24, No. 2, 1950, pp. 18-20.

[4] George Harris, "A Church Filled with Moslems", China's Millions, Vol. 76, No. 7-8, 1950, pp. 80-81.

[5] Laurie C. Wood, "The Reproach Islam in Northwest China", China's Millions, Vol. 77, No. 11, 1950, pp. 104-106.

[6] Claude L Pickens, "Annotated Bibliography of Literature on Islam in China", Published by Society of Friends of the Moslems in China, 1950.

[7] Rudolf Loewenthal, "Russian Materials on Islam in China: A Preliminary Bibliography", Monumenta Serica Journal of Oriental Studies, Vol. 16, No. 1/2, 1957, pp. 449-479.

[8] Ludmilla Panskaya and Donald Daniel Leslie, "Introduction to Palladii's Chinese Literature of the Muslims", Faculty of Asian Studies, Australian National University Press (Oriental Monographs Series No. 20) 1977. "Book Reviews". 
[9] Vasilij Pavlovich Vasil've (Translated from the Russian) by Rudolf Loewenthal, "Islam in China" (Central Asian Collectanea, No. 3), Published by Washington, D. C, 1960, 37 pages.

[10] M. Rafiq Khan, "Islam in China", Delhi: National Academy, 1963, 144 pages. and Map. Rs. 5.

[11] Barbara L. K. Pillsbury, "Cohesion and Cleavage in a Chinese Muslim Minority”, Columbia University, 1973.

[12] Richard V. Weekes, "Muslim Peoples: A World Ethnographic Survey", Greenwood Press: Westport, Connecticut, 1978.

[13] June Teufel Dreyer, China's Forty Millions: Minority Nationalities and National Integration in- the People's Republic of China, Harvard University Press, 1976.

[14] Dawood C. M. Ting, "Islamic Culture in China" In Islam the Straight Path; Islam Interpreted by Muslims, edited by Kenneth W. Morgan, New York: Ronald, 1958, Chapter 9.

[15] Rossabi, Morris. "Muslim and Central Asian Revolts." From Ming to Ch'ing: Conquest, Region, and Continuity in Seventeenth-Century China edited by Jonathan D. Spence and John E. Wills, 167-199. New Haven: Yale University Press, 1979, pp. 167-199.

[16] Pudolf Loewenthal, "Russian Contributions to the History of Islam in China", Central Asiatic Journal, Vol. 7, No. 4, 1962, pp. 312-315.

[17] Francois Joyaux, "Les Musulmans en Chine Populaire: Problems Politiques Sociauxet Conomiquesdes Minorits Musulmansdela Chine Populaire, 1950-1960", In the review and research of literature, No. 2915, 1962 (published by the French government) 76 pages in total. (French).

[18] Francois Joyaux, "Les Minorits-Musulmansen Chine Populaire", L. Afriqueet L. Asie, No. 68, 1964, pp. 3-12. (French).

[19] Francois Joyaux, "Les Musulmans de Chine et la Diplomatie de Pekin", L. Afriqueet L. Asie, No. 77, 1967, pp. 17-24. (French).

[20] Jesef Trippner "Dir Salaren, Ihre Ersten GraubeansStreitigkeiten und Ihr Aufstand 1781", Central Asiatic Journal, Vol. 9, 1964, pp. 241-276. (German).

[21] Jesef Trippner, "Islamiche Gruppen und Druberkult in Nord-west Chine", Die Welt des Islams, 1961. pp. 143-171. (German)

[22] Published in the collection of "Der Orient in Forschung: Festschrift fur Otto Spies Zum 5 April 1966, ed Wilhelm Hoenerbach (Wiesbaden: Otto Harrassowitz, 1967), pp. 202 208 .

[23] Muk-hammed Sushanlo, "Dungane: Istorko-eth-nograficheckiiocherk", FRUNZE, 1971, pp. 305. (Russian).

[24] Svetlana Rimsky-Korsakoff Dyer," Soviet Dungan; the Chinese Language of Central Asia, Alphabet, Phonology, Morphology", Monumenta Serica, 1967. (Russian).

[25] Svetlana Rimsky-Korsakoff Dyer, "Soviet Dungan Nationalism; A few Comments on Their Origin and Language", Monumenta Serica, 1977-1978. (Russian).

[26] Svetlana Rimsky-Korsakoff Dyer, "Soviet Dungan Weddings; Smbolism and Traditions", Monumenta Serica, 1977-1978. (Russian).
[27] Svetlana Rimsky-Korsakoff Dyer, "Muslim Life in Soviet Russia; the Case of Dungans", Journal of the Muslim Minority Affairs Society, Vol. 2, No. 2 and Vol. 3, No. 3, 1980-1981, pp. 42-54. (Russian).

[28] Raphael Israeli "Muslims in China: A Study in Cultural Confrontation", London: Curzon Press, 1979. "Book Reviews".

[29] Raphael Israeli, "Islam in China: A Critical Bibliography", With the assistance of Lyn Corman, London: Greenwood Press, 1994.

[30] Raphael Israeli, "The Cross Battles the Crescent: One Century of Missionary Work among Chinee Muslims (1850-1950)", Modern Asian Studies, Vol. 29, No. 1, 1995.

[31] Raphael Israeli, "The Muslim Revival in $19^{\text {th }}$ Century China", Studia Islamica, Vol. 43, 1976, pp. 119-138.

[32] Raphael Israeli, "Muslims in China: Incompatibility between Islam and the Chinese Order", T'oung Pao, Vol. 63, 1978, pp. 296-323.

[33] Raphael Israeli, "Established Islam and Marginal Islam in China: From Eclecticism to Syncretism", Journal of the Economic and Social History of the Orient, Vol. 21, No. 1, 1978, pp. 99-109.

[34] Raphael Israeli, "Ahung and Literatus: A Muslim Elite in Confucian China", Die Welt des Islams, Vol. 19, 1979, pp. 212 219.

[35] Raphael Israeli, "Muslim in China: Islam's s Incompatibility with the Chinese Order", T'OUNG PAO, Second Series, Vol. 63, Livr. 4/5, 1977, pp. 296-323.

[36] Raphael Israeli, "An Arabic Manuscript on China and Tibet", Arabica, Vol. 39, 1992, pp. 207-215.

[37] Dru C. Gladney, Muslim Chinese: Ethnic Nationalism in The People's Republic, Harvard University Press, 1990.

[38] Dru C. Gladney "Qingzhen: A Study of Ethnoreligious Identity among Hui Muslim Communities in China", in 1991, Harvard University Press published its revised monograph based on Doctoral dissertation.

[39] Dru C. Gladney "Ethnic Identity in China: The Making of A Muslim Minority Nationality", Orlando: Hardcourt Brace \& Company, 1998).

[40] Dru C. Gladney "Ethnic Identity in China: The Making of a Muslim Minority Nationality", Orlando: Hardcourt Brace \& Company, 1998, 195 pages, a review.

[41] Wang Jianping, Concord, and Conflict: The Hui Communities of Yunnan Society in a Historical Perspective, Stockholm International Book Company, 1996.

[42] Anthony R. Walker, "Book Review", Asian Folklore Studies, Vol. 57, No. 1, 1998, pp. 167-169.

[43] (Matumoto Masumi, Firs systematic study on the Yunnan tribe, Eastern, Vol. 211, 1998, pp 34-37.

[44] Joseph F. Fletcher, "Chinese Sufism Taoism", In the mystical order in Islam and its development and current situation, edited by Popovich and Van Stein, Paris Academy of Social Sciences, 1986, pp. 13-26.

[45] Joseph F. Fletcher, Beatrice Forbes Manz., Studies on Chinese and Islamic inner Asia, Alder shot: Variorum, 1995. 
[46] Jonathan N, Lipman, Familiar Strangers: A History of Muslims in Northwest China, University of Washington Press, 1997.

[47] Jonathan Lipman, "Pieced together and meshed Society: a study of the Chinese Muslim order", Islam in Asia, Vol. 11 (Special issue of Southeast Asia and East Asia (edited by Rafael in Israel), 1984 (Jerusalem), pp. 246-274.

[48] Jonathan Lipman, "Nationality and politics of the people's Republic of China, the malanite warlords in Gansu Province", Modern China, Vol. 10, No 3, 1984, pp. 285-316.

[49] Donald Daniel Leslie, Islamic Literature in Chinese Late Ming and Early Qing: Books, Authors, and Associates, Canberra College of Advanced Education, 1981.

[50] Donald Daniel, "The Identification of Chinese Cities in Arabic and Persian Sources", The history of the Far East, Vol. 26, 1982, pp. 1-18.

[51] Donald Daniel Leslie, Mohamed Wassel, "Arabic and Persian sources used by Liu Chi”, Central Asiatic Journal, Vol. 29, No. 1/2, 1982, pp. 78-104.

[52] Donald Daniel Leslie, "Islam in Traditional China: A short History to 1980", Canberra College of Advanced Education, 1986.

[53] Donald Daniel Leslie, "Islam in china to 1800: Bibliographical Guide” Abr Nahrain, Vol. 16, 1976, pp. 16-48.

[54] Donald Daniel Leslie, "Arabic and Persian Sources Used by Liu Chih", Central Asia Magazine, Vol. 26, 1982, pp. 78-104.

[55] Francois Orban "the Origin of Islam in China", Knowledge Dissemination around the Muslim World, Vol. 3, 1985, pp. 144-147.

[56] Michael Dillon, "China's Muslims (Images of Asia)", New York: Oxford University Press, 1996.
[57] Reference web: https://www.amazon.com/Chinas-Muslims-Images-Michael-D illon/dp/0195875044

[58] Michael Dillon, "China's Muslim Hui Community: Migration, Settlement, and Sects", Richmond, London: Curzon Press, 1999.

[59] Ma tong's A brief history of Chinese Islamic sect and Menhuan system, Ningxia people's Publishing house, 2000, 391 pags.

[60] Barbara L. K. Pillsbury, "The history of Muslims in China, a chronology of 1300", Journal of the Institute of Muslim Minority Affairs, Vol. 3, No. 2, pp. 10-29, 1981.

[61] Andrew. D. W Forbes, "Warlords and Muslims in Chinese Central Asia: A Political History of Republican Sinkiang (1911-1949)", Cambridge University Press, 1986.

[62] Morris Rossabi, "China and the Islamic World", Comparative Civilizations Review, Vol. 13, No. 13, 1985, pp. 269-283.

[63] Morris Rossabi, "Islam in China" in Mircea Eliade, ed, The Encyclopedia of Religion, New York: Macmillan, 1987, 7: 384.

[64] Abdul Wahid Radhu, "ISLAM IN TIBET-TIBETAN CARAVANS", Editor by Gray Henry, Translated by Jane Casewit, Fons Vitae, 1997, Louisville. -https://fonsvitae.com/product/islam-in-tibet/

[65] Benson, Linda, and Ingvar Svanberg. China's Last Nomads: The History and Culture of China's Kazaks. Armonk, NY: M. E. Sharpe, 1998.

[66] Larry N. Shyu, "Reviewed Work: China's Last Nomads: The History and Culture of China's Kazaks by Linda Benson", China Review International, Vol. 6, No. 2, 1999, pp. 378-380. 